\title{
PERTUMBUHAN DAN HASIL TIGA KULTIVAR KACANG HIJAU PADA JARAK TANAM YANG BERBEDA
}

\section{GROWTH AND YIELD OF THREE MUNGBEAN CULTIVARS AT DIFFERENT PLANT SPACING}

\author{
Umi Trisnaningsih ${ }^{1}$, Siti Wahyuni $^{1}$, dan Meilina Prasetyo ${ }^{2}$ \\ ${ }^{1}$ Program Studi Agroteknologi, Fakultas Pertanian Universitas Swadaya Gunung Jati (UGJ) \\ ${ }^{2}$ Program Studi Agronomi, Sekolah Pascasarjana UGJ \\ Email:umitrisna@gmail.com
}

\begin{abstract}
Growth and Yield of Three Mungbean Cultivars at Different Plant Spacing. This study aims to determine the growth and yield of three mungbean cultivars at different plant spacing. Experiments were carried out at the Experimental Garden, Faculty of Agriculture UGJ from October 2016 to February 2017. The materials used are mungbean seeds cultivar Walet, Murai, and Vima 1, fertilizers Urea, SP 36 and KCl. The experiment was arranged in a Randomized Complete Block Design, with factorial pattern.The first factor is plant spacing with three levels $(15 \mathrm{~cm} \times 30 \mathrm{~cm} ; 20 \mathrm{~cm} \times 30 \mathrm{~cm}$; and $25 \mathrm{~cm} \times 30 \mathrm{~cm})$ and and the second factor is cultivar with three levels (Walet, Murai and Vima 1). All treatments were repeated three times. The variables observed consisted of plant height, number of branches per plant, leaf area index (LAI) and shoot-root ratio, which was observed at age 21, 28 and 35 days after planting. The yield components, which were observed at harvest included: number of pods per plant and per plot, the weight of 100 dry seeds, harvest index, and seed weight per plant and per plot. The heist yield for Walet and Murai achieved from plant spacing $15 \mathrm{~cm} \times 30 \mathrm{~cm}\left(663,34 \mathrm{~g} \mathrm{petak}^{-1}\right.$ dan 337,46 g petak ${ }^{-1}$ respectively), for Vima-1 achieved from $20 \mathrm{~cm} \times 30 \mathrm{~cm}\left(385,63 \mathrm{~g}\right.$ petak $\left.^{-1}\right)$.
\end{abstract}

Key words: Cultivar, Mungbean, Plant Spacing

\begin{abstract}
ABSTRAK
Pertumbuhan dan Hasil Tiga Kultivar Kacang Hijau pada Jarak Tanam yang Berbeda. Penelitian ini bertujuan untuk mengetahui pertumbuhan dan hasil tiga kultivar tanaman kacang hijau pada jarak tanam yang berbeda. Percobaan dilakukan di Kebun Percobaan Fakultas Pertanian UGJ, mulai bulan Oktober 2016 sampai bulan Februari 2017. Bahan yang digunakan dalam penelitian ini adalah benih kacang hijau kultivar Walet, Murai, dan Vima 1 serta pupuk Urea, SP 36 dan KCl. Percobaan disusun secara Rancangan Acak Kelompok pola faktorial.Faktor pertama adalah jarak tanam dengan tiga taraf $(15 \mathrm{~cm} \times 30 \mathrm{~cm} ; 20 \mathrm{~cm} \times 30 \mathrm{~cm}$; dan $25 \mathrm{~cm} \times 30$ $\mathrm{cm}$ ). Sedangkan faktor kedua adalah kultivar yang terdiri dari tiga taraf (Walet, Murai dan Vima 1). Semua perlakuan diulang tiga kali. Variabel yang diamati terdiri dari tinggi tanaman, jumlah cabang per tanaman, indeks luas daun (ILD) serta rasio pucuk akar (RPA), yang diamati pada umur 21, 28 dan 35 HST. Komponen hasil, yang diamati pada saat panen meliputi: jumlah polong per tanaman dan per petak, bobot 100 butir biji kering, indeks panen, serta bobot biji per tanaman dan per petak. Hasil tertinggi kultivar Walet dan Murai diperoleh
\end{abstract}


pada jarak tanam $15 \mathrm{~cm}$ x $30 \mathrm{~cm}\left(663,34\right.$ g petak $^{-1}$ dan 337,46 g petak ${ }^{-1}$ berturut-turut), sementara Vima-1 diperoleh pada jarak tanam $20 \mathrm{~cm}$ x $30 \mathrm{~cm}\left(385,63 \mathrm{~g} \mathrm{petak}^{-1}\right)$.

Kata kunci: Galur, padi gogo, preferensi petani

\section{PENDAHULUAN}

Kacang hijau merupakan salah satu tanaman sumber protein yang penting di Indonesia. Kandungan lisinnya yang tinggi dapat menjadi pelengkap untuk beras yang kandungan lisinnya rendah (Trustinah et al. 2014). Kelebihan lain dari tanaman kacang hijau adalah mudah dibudidayakan, daya adaptasinya luas, serta toleran terhadap kekeringan (Arsyadmunir 2016). Kacang hijau cocok ditanam pada ketinggian sampai dengan $500 \mathrm{~m}$ di atas permukaan laut (dpl), dengan suhu ratarata $25^{\circ} \mathrm{C}-27^{\circ} \mathrm{C}$, kelembaban relatif $50 \%$ - $80 \%$, serta curah hujan rata-rata $50 \mathrm{~mm}-200 \mathrm{~mm}$ per bulan (Sunghening, Tohari, dan Shiddieq 2013).

Namun demikian, dari aspek budidaya kacang hijau kurang mendapatkan perhatian petani sehingga hasil per hektarnya masih jauh lebih rendah dari potensi hasilnya. Peningkatan hasil tanaman kacang dapat hijau dilakukan dengan cara memperbaiki kultur teknis, seperti penggunaan kultivar baru yang berdaya hasil tinggi dan masak serempak, serta pengaturan jarak tanam. Hasil penelitian Seran, Kote, dan Benu (2011), menunjukkan bahwa kultivar Vima-1 yang ditanam dengan menerapkan komponen teknologi anjuran di musim kemarau, memberikan hasil 0,97 tha ${ }^{-1}$ namun apabila ditanam dengan jarak tanam yang tidak teratur hanya akan menghasilkan 0,47 $\mathrm{t} \mathrm{ha}^{-1}$. Hal ini menunjukkan bahwa jarak tanam berperan penting dalam meningkatkan hasil tanaman kacang hijau. Hasil penelitian di Kabupaten Demak menunjukkan bahwa untuk kultivar Vima-1, petani masih menggunakan jarak tanam $40 \mathrm{~cm} \times 20 \mathrm{~cm}$ padahal jarak tanam anjurannya adalah $40 \mathrm{~cm}$ x $15 \mathrm{~cm}$. Dengan demikian populasi tanaman menjadi lebih sedikit. Hal ini yang menyebabkan hasilnya menjadi lebih rendah (Radjit dan Prasetiaswati 2012).

Jarak tanam akan menentukan jumlah populasi per satuan luas atau kerapatan tanam. Kerapatan tanam akan berpengaruh terhadap komponen hasil maupun hasil biji kacang hijau (Kabir and Sarkar 2008; Marliah, Hidayat, dan Husna 2012). Oleh karena itu, jarak tanam harus diatur sedemikian rupa agar dapat menyediakan lingkungan yang mendukung pertumbuhan dan hasil tanaman kacang hijau (Ahamed et al. 2011).

Penelitian padakedelai memperlihatkan adanya interaksi yang nyata antara kultivar yang diuji dengan jarak tanam terhadap jumlah polong total dan polong bernas per tanaman serta bobot biji per tanaman (Marliah, Hidayat, dan Husna 2012). Hal ini menunjukkan bahwa jarak tanam yang optimal tidak sama untuk setiap kultivar. Berbagai penelitian pada kacang hijau memperlihatkan jarak tanam optimal yang berbeda, Hasil penelitian pada kacang hijau kultivar Kutilang menunjukkan bahwa jarak tanam yang terbaik 
adalah $15 \mathrm{~cm}$ x $30 \mathrm{~cm}$ (Marsiwi, Purwanti, dan Prajitno 2015). Sementara jarak tanam anjuran untuk kultivar Vima-1 adalah 40cm x 20 cm (Seran et al., 2011;Radjit dan Prasetiaswati, 2012). Namun demikian, hasil penelitian Putra, Wijana, \& Dinata (2016) menunjukkan bahwa pada jarak tanam $20 \mathrm{~cm} \times 30$ cm, kultivar Vima-1 memberikan hasil terbaik pada perlakuan jumlah benih per 3 butir per lubang tanam. Hal ini menunjukkan bahwa dengan jumlah populasi per satuan luas yang lebih padat, kultivar Vima-1 masih memberikah hasil yang terbaik.

Berdasarkan hasil-hasil penelitian tersebut dapat disimpulkan bahwa jarak tanam yang optimal akan berbeda untuk kultivar maupun lingkungan yang berbeda. Penelitian ini bertujuan untuk mengetahui jarak tanam terbaik bagi tiga kultivar kacang hijau yang diuji pada musim penghujan di lahan kering.

\section{BAHAN DAN METODE}

Percobaan dilaksanakan di Kebun Percobaan Fakultas Pertanian Unswagati Kampus Gunungjati (GT), Kelurahan Sunyaragi, Kecamatan Kesambi Cirebon, Kota Cirebon Jawa Barat. Lokasi tersebut terletak pada ketinggian $7 \mathrm{~m}$ dpl. Waktu percobaan dimulai dari bulan Oktober 2016 sampai bulan Februari 2017. Bahan yang digunakan adalah benih kacang hijau kultivar Walet, Mura, dan Vima 1, pupuk Urea, SP 36 dan $\mathrm{KCl}$, serta insektisida dan fungisida. Alat yang digunakan antara lain cangkul, kored, tugal, penggaris, timbangan, oven, dan alat tulis.

Rancangan yang digunakan dalam penelitian ini adalah rancangan acak kelompok (RAK) pola faktorial. Faktor pertama adalah kultivar kacang hijau dengan tiga taraf, yaitu: Walet, Murai, dan Vima 1. Faktor yang kedua adalah jarak tanam dengan tiga taraf perlakuan: $15 \mathrm{~cm}$ x $30 \mathrm{~cm}, 20 \mathrm{~cm}$ x $30 \mathrm{~cm}$, dan $25 \mathrm{~cm}$ x $30 \mathrm{~cm}$. Masing-masing perlakuan diulang $3 \mathrm{kali}$ sehingga terdapat 27 petak percobaan. Ukuran petak yang digunakan $120 \mathrm{~cm}$ x $110 \mathrm{~cm}$, jarak antar-petak $30 \mathrm{~cm}$, jarak antar-ulangan $50 \mathrm{~cm}$ dan tinggi bendengan $30 \mathrm{~cm}$.

Pengamatan utama meliputi komponen pertumbuhan yaitu: tinggi tanaman, jumlah cabang per tanaman, indeks luas daun (ILD) serta rasio pucuk akar (RPA), yang diamati pada umur 21, 28 dan 35 HST. Komponen hasil, yang diamati pada saat panen meliputi: jumlah polong per tanaman dan per petak, bobot 100 butir biji kering, indeks panen, serta bobot biji per tanaman dan per petak. Untuk mengetahui apakah ada pengaruh dari perlakuan digunakan Uji F sementara untuk mengetahui perbedaan antar-perlakuan digunakan Uji LSD.

\section{HASIL DAN PEMBAHASAN}

Hasil Uji F menunjukkan bahwa tidak terjadi interaksi antara perlakuan jarak tanam dengan kultivar kacang hijau pada semua umur pengamatan (hasil analisis tidak ditampilkan)). Secara mandiri, baik jarak tanam maupun kultivar tidak berpengaruh nyata terhadap tinggi tanaman pada semua umur pengamatan (Tabel 1).

Pertambahan tinggi tanaman merupakan indikator pertumbuhan tanaman. Tidak adanya pengaruh jarak tanam pada tiga kultivar kacang hijau 
Tabel 1. Pengaruh Jarak Tanam dan Kultivar Terhadap Tinggi Tanaman Umur 21, 28, dan 35 HST

\begin{tabular}{lrcc}
\hline \multirow{2}{*}{ Perlakuan } & \multicolumn{3}{c}{ Rata-Rata Tinggi Tanaman $(\mathrm{cm})$} \\
\cline { 2 - 4 } Jarak Tanam: & $21 \mathrm{HST}$ & $28 \mathrm{HST}$ & 35 HST \\
$15 \mathrm{~cm} \times 30 \mathrm{~cm}$ & $10,30 \mathrm{a}$ & $14,57 \mathrm{a}$ & $25,91 \mathrm{a}$ \\
$20 \mathrm{~cm} \times 30 \mathrm{~cm}$ & $10,32 \mathrm{a}$ & $14,37 \mathrm{a}$ & $21,20 \mathrm{a}$ \\
$25 \mathrm{~cm} \times 30 \mathrm{~cm}$ & $10,57 \mathrm{a}$ & $13,81 \mathrm{a}$ & $22,47 \mathrm{a}$ \\
Kultivar & & & \\
Walet & $12,09 \mathrm{a}$ & $15,39 \mathrm{a}$ & $23,84 \mathrm{a}$ \\
Murai & $9,42 \mathrm{a}$ & $14,88 \mathrm{a}$ & $24,15 \mathrm{a}$ \\
Vima-1 & $9,69 \mathrm{a}$ & $12,49 \mathrm{a}$ & $21,59 \mathrm{a}$ \\
\hline
\end{tabular}

Keterangan: Angka rata-rata yang diikuti huruf yang sama pada kolom yang sama menunjukan tidak berbeda nyata menurut LSD pada taraf $5 \%$.

Tabel 2. Pengaruh Jarak Tanam dan Kultivar Terhadap Jumlah Cabang Umur 21, 28, 35 dan 42 HST

\begin{tabular}{cccc}
\hline \multirow{2}{*}{ Perlakuan } & \multicolumn{3}{c}{ Rata-Rata Jumlah Cabang (buah) } \\
\cline { 2 - 3 } Jarak Tanam: & $21 \mathrm{HST}$ & $28 \mathrm{HST}$ \\
$15 \mathrm{~cm} \times 30 \mathrm{~cm}$ & $1,69 \mathrm{a}$ & $4,61 \mathrm{a}$ \\
$20 \mathrm{~cm} \times 30 \mathrm{~cm}$ & $1,48 \mathrm{a}$ & $3,47 \mathrm{a}$ & $5,79 \mathrm{~b}$ \\
$25 \mathrm{~cm} \times 30 \mathrm{~cm}$ & $2,42 \mathrm{a}$ & $2,83 \mathrm{a}$ & $5,70 \mathrm{~b}$ \\
Kultivar & $1,72 \mathrm{a}$ & $4,18 \mathrm{a}$ & $5,53 \mathrm{~b}$ \\
Walet & $1,46 \mathrm{a}$ & $3,05 \mathrm{a}$ & $4,62 \mathrm{a}$ \\
Murai & $2,41 \mathrm{a}$ & $3,20 \mathrm{a}$ & $5,96 \mathrm{~b}$ \\
Vima-1 & $4,24 \mathrm{a}$ &
\end{tabular}

Keterangan: Angka rata-rata yang diikuti huruf yang sama pada kolom yang sama menunjukan tidak berbeda nyata menurut LSD pada taraf $5 \%$.

menunjukkan bahwa jarak tanam yang digunakan masih memadai untuk mendukung pertumbuhan ketiga kultivar kacang hijau yang berbeda. Hasil penelitian ini berbeda dengan hasil penelitian Rasul, Cheema, Sattar, Saleem, dan Wahid (2012) di Pakistan, yang menunjukkan bahwa jarak antar-barisan berpengaruh nyata terhadap tinggi tanaman tiga kultivar kacang hijau yang diuji. Namun demikian, hasil penelitian ini sama dengan hasil penelitian Kuntyastuti dan Lestari (2017), yang menunjukkan bahwa kerapatan tanam tidak berpengaruh terhadap tinggi tanaman kacang hijau kultivar Vima 1.

Uji F menunjukkan tidak terjadi interaksi antara pengaruh jarak tanam dengan kultivar terhadap jumlah cabang per tanaman pada semua umur pengamatan (hasil analisis tidak ditampilkan). Secara mandiri jarak tanam dan kultivar tidak berpengaruh nyata terhadap jumlah cabang per tanaman, pada umur 21 dan 28 HST, tetapi berpengaruh nyata pada umur 35 HST (Tabel2).

Jarak tanam $15 \mathrm{~cm}$ x $30 \mathrm{~cm}$ menghasikan 
cabang yang paling sedikit dibanding dua jarak tanam lainnya. Hasil ini menunjukkan bahwa pada jarak tanam $15 \mathrm{~cm}$ x $30 \mathrm{~cm}$, semua kultivar tidak dapat tumbuh dengan optimal, sehingg hanya sedikit cabang yang dihasilkan. Sedikitnya cabang menunjukkan gejala adanya etiolasi, pertumbuhan batang yang lebih tinggi akibat kekurangan sinar matahari. Pada jarak tanam yang lebih lebar, kacang hijau mampu menghasilkan cabang yang lebih banyak.

Pada Tabel 2 dapat dilihat bahwa kultivar Murai menghasilan cabang yang paling sedikit bila dibandingkan dua kultivar lainnya, yaitu antara $4-5$ cabang per tanaman. Hal ini diduga karena tipe pertumbuhan yang berbeda antara Murai dengan Walet dan Vima-1.Pada penelitian Kabir dan Sarkar (2008) diketahui bahwa jarak tanam berpengaruh terhadap jumlah cabang per tanaman. Sementara hasil penelitian Rasul et al. (2012) menunjukkan, terjadi interaksi yang nyata antara jarak tanam dan kultivar terhadap jumlah cabang per tanaman. Namun demikian, hasil penelitian Chaniago, Purba, dan Utama (2017) menunjukkan perlakuan jarak tanam tidak berpengaruh nyata terhadap jumlah cabang per tanaman pada kultivar Kutilang.

Terjadi interaksi yang nyata antara perlakuan jarak tanam dengan kultivar terhadap indeks luas daun (ILD) pada semua umur pengamatan (hasil analisis tidak ditampilkan). Pada umur 21 HST, jarak tanam berpengaruh nyata terhadap ILD pada semua kultivar yang diuji (Tabel 3).

Pada Tabel 3 dapat dilihat bahwa pada jarak tanam $15 \mathrm{~cm}$ x $30 \mathrm{~cm}$, kultivar Walet memberikan ILD yang lebih tinggi dibanding dua kultivar lainnya. Sementara pada jarak tanam $25 \mathrm{~cm}$ x $30 \mathrm{~cm}$ kultivar Vima-1 memberikan ILD yang paling tinggi.

Pada Tabel 4 dapat dilihat bahwa pada umur 28 HST, ILD kultivar Walet dan Murai tidak dipengaruhi oleh jarak tanam yang diuji sementara pada Vima-1, semakin lebar jarak tanam maka ILD-nya semakin besar. Pada jarak tanam $25 \mathrm{~cm}$ x $30 \mathrm{~cm}$, kultivar Vima-1 ILD yang lebih besar dibanding dua kultivar lainnya.

Pada umur 35 HST dapat dilihat pada kultivar Walet dan Vima-1, semakin lebar jarak tanam maka

Tabel 3. Pengaruh Jarak Tanam dan Kultivar Terhadap Indeks Luas Daun (ILD) Umur 21 HST

\begin{tabular}{cccc}
\hline Perlakuan & $15 \mathrm{~cm} \times 30 \mathrm{~cm}$ & $20 \mathrm{~cm} \times 30 \mathrm{~cm}$ & $25 \mathrm{~cm} \times 30 \mathrm{~cm}$ \\
\hline Walet & $0,17 \mathrm{~b}$ & $0,17 \mathrm{a}$ & $0,09 \mathrm{a}$ \\
& $\mathrm{A}$ & $\mathrm{A}$ & $\mathrm{A}$ \\
Murai & $0,15 \mathrm{a}$ & $0,11 \mathrm{a}$ & $0,10 \mathrm{a}$ \\
& $\mathrm{A}$ & $\mathrm{A}$ & $\mathrm{A}$ \\
Vima- & $0,05 \mathrm{a}$ & $1,10 \mathrm{a}$ & $0,53 \mathrm{~b}$ \\
& $\mathrm{~A}$ & $\mathrm{AB}$ & $\mathrm{B}$ \\
\hline
\end{tabular}

Keterangan: Angka rata-rata yang diikuti huruf kapital yang sama pada baris yang sama dan huruf kecil yang sama pada kolom yang sama menunjukan tidak berbeda nyata menurut Uji LSD pada taraf $5 \%$. 
Tabel 4. Pengaruh Jarak Tanam dan Kultivar Terhadap Indeks Luas Daun (ILD) Umur 28 HST

\begin{tabular}{cccc}
\hline Perlakuan & $15 \mathrm{~cm} \times 30 \mathrm{~cm}$ & $20 \mathrm{~cm} \times 30 \mathrm{~cm}$ & $25 \mathrm{~cm} \times 30 \mathrm{~cm}$ \\
\hline Walet & $0,42 \mathrm{~b}$ & $0,34 \mathrm{a}$ & $0,33 \mathrm{a}$ \\
& $\mathrm{A}$ & $\mathrm{A}$ & $\mathrm{A}$ \\
Murai & $0,50 \mathrm{~b}$ & $0,38 \mathrm{a}$ & $0,23 \mathrm{a}$ \\
& $\mathrm{A}$ & $\mathrm{B}$ & $\mathrm{B}$ \\
Vima-1 & $0,23 \mathrm{a}$ & $0,44 \mathrm{a}$ & $0,78 \mathrm{~b}$ \\
& $\mathrm{~A}$ & $\mathrm{~B}$ & $\mathrm{C}$ \\
\hline
\end{tabular}

Keterangan: Angka rata-rata yang diikuti huruf kapital yang sama pada baris yang sama dan huruf kecil yang sama pada kolom yang sama menunjukan tidak berbeda nyata menurut Uji LSD pada taraf $5 \%$.

Tabel 5. Pengaruh Jarak Tanam dan Kultivar Terhadap Indeks Luas Daun Umur 35 HST

\begin{tabular}{cccc}
\hline Perlakuan & $15 \mathrm{~cm} \times 30 \mathrm{~cm}$ & $20 \mathrm{~cm} \times 30 \mathrm{~cm}$ & $25 \mathrm{~cm} \times 30 \mathrm{~cm}$ \\
\hline Walet & $1,68 \mathrm{~b}$ & $2,12 \mathrm{~b}$ & $2,54 \mathrm{~b}$ \\
& $\mathrm{~A}$ & $\mathrm{AB}$ & $\mathrm{B}$ \\
Murai & $1,40 \mathrm{ab}$ & $1,39 \mathrm{a}$ & $0,80 \mathrm{a}$ \\
& $\mathrm{A}$ & $\mathrm{A}$ & $\mathrm{A}$ \\
Vima-1 & $0,80 \mathrm{a}$ & $1,19 \mathrm{a}$ & $1,81 \mathrm{~b}$ \\
& $\mathrm{~A}$ & $\mathrm{AB}$ & $\mathrm{B}$ \\
\hline
\end{tabular}

Keterangan: Angka rata-rata yang diikuti huruf kapital yang sama pada baris yang sama dan huruf kecil yang sama pada kolom yang sama menunjukan tidak berbeda nyata menurut Uji LSD pada taraf 5\%.

akan semakin besar ILD-nya. Pada kultivar Murai, ILD tidak dipengaruhi oleh jarak tanam (Tabel 5).

ILD yang tinggi menunjukkan antara satu tajuk dengan tajuk lainnya saling menutupi akibat jarak tanam yang terlalu sempit. ILD yang besar menunjukkan bahwa ruang tumbuh yang tersedia lebih sempit dibandingkan dengan luas daun tanaman. Hal ini akan mengakibatkan adanya daun yang saling menutupi sehingga tidak memperoleh sinar matahari yang cukup. Daun yang tidak memperoleh sinar matahari tidak dapat melakukan fotosintesis tetapi hanya menjadi limbung (sink) untuk menampung hasil fotosintesis (Hopkins dan Hunner 2009).

Hasil penelitian yang sama diperoleh pada penelitian lain yang menggunakan kultivar Kutilang
(Marsiwi, Purwanti, dan Prajitno 2015). Namun pada penelitian dengan perlakuan jumlah benih per lubang pada kultivar Vima-1, menunjukkan semakin padat populasi tanaman luas daunnya akan semakin lebar (Putra, Wijana, dan Dinata 2016). Hal ini berarti pada populasi yang lebih padat atau pada jarak tanam yang lebih sempit, akan diperoleh indeks luas daun yang lebih besar.

Hasil Uji F menunjukkan tidak terjadi interaksi antara pengaruh jarak tanam dan kultivar terhadap rasio pucuk akar(RPA) pada semua umur pengamatan (hasil analisis tidak ditampilkan). Secara mandiri, baik jarak tanam maupun kultivar tidak berpengaruh nyata terhadap rasio pucuk akar (RPA) pada semua kultivar, pada semua umur pengamatan (Tabel 6). 
Tabel 6. Pengaruh Jarak Tanam dan Kultivar Terhadap Rasio Pucuk Akar Umur 21, 28 dan 35 HST

\begin{tabular}{|c|c|c|c|}
\hline \multirow{2}{*}{ Perlakuan } & \multicolumn{3}{|c|}{ Rasio Pucuk Akar } \\
\hline & $21 \mathrm{HST}$ & $28 \mathrm{HST}$ & $35 \mathrm{HST}$ \\
\hline \multicolumn{4}{|l|}{ Jarak Tanam: } \\
\hline $15 \mathrm{~cm} \times 30 \mathrm{~cm}$ & $5,86 \mathrm{a}$ & $6,71 \mathrm{a}$ & $4,99 \mathrm{a}$ \\
\hline $20 \mathrm{~cm} \times 30 \mathrm{~cm}$ & $2,66 \mathrm{a}$ & $5,26 \mathrm{a}$ & $5,83 \mathrm{a}$ \\
\hline $25 \mathrm{~cm} \times 30 \mathrm{~cm}$ & $5,40 \mathrm{a}$ & $9,38 \mathrm{a}$ & $5,81 \mathrm{a}$ \\
\hline \multicolumn{4}{|l|}{ Kultivar } \\
\hline Walet & $5,80 \mathrm{a}$ & 7,48 a & 5,48 a \\
\hline Murai & $4,87 \mathrm{a}$ & $6,63 \mathrm{a}$ & $4,70 \mathrm{a}$ \\
\hline Vima-1 & $3,24 \mathrm{a}$ & $7,24 \mathrm{a}$ & $6,08 \mathrm{a}$ \\
\hline
\end{tabular}

Keterangan: Angka rata-rata yang diikuti huruf yang sama pada kolom yang sama menunjukan tidak berbeda nyata menurut LSD pada taraf $5 \%$.

Tabel 7. Pengaruh Jarak Tanam dan Kultivar Terhadap Jumlah Polong Per Tanaman

\begin{tabular}{cccc}
\hline Perlakuan & $15 \mathrm{~cm} \times 30 \mathrm{~cm}$ & $20 \mathrm{~cm} \times 30 \mathrm{~cm}$ & $25 \mathrm{~cm} \times 30 \mathrm{~cm}$ \\
\hline Walet & $99,03 \mathrm{a}$ & $99,89 \mathrm{~b}$ & $87,00 \mathrm{a}$ \\
& $\mathrm{A}$ & $\mathrm{A}$ & $\mathrm{A}$ \\
Murai & $102,52 \mathrm{a}$ & $47,17 \mathrm{a}$ & $74,50 \mathrm{a}$ \\
& $\mathrm{A}$ & $\mathrm{A}$ & $\mathrm{A}$ \\
Vima-1 & $83,96 \mathrm{a}$ & $108,00 \mathrm{~b}$ & $134,50 \mathrm{~b}$ \\
& $\mathrm{~A}$ & $\mathrm{~A}$ & $\mathrm{~A}$ \\
\hline
\end{tabular}

Keterangan: Angka rata-rata yang diikuti huruf kapital yang sama pada baris yang sama dan huruf kecil yang sama pada kolom yang sama menunjukan tidak berbeda nyata menurut Uji LSD pada taraf $5 \%$.

RPAadalah perbandingan antara bobot kering akar dengan bobot kering bagian atas tanaman. Hasil penelitian kacang hijau pada kerapatan tanam yang berbeda menunjukkan bahwa kerapatan tanam tidak berpengaruh nyata baik terhadap bobot kering akar maupun bobot kering tanaman (Kuntyastuti dan Lestari 2017). Hal ini menunjukkan hasil penelitian yang sama dengan hasil penelitian ini.

Terjadi interaksi antara jarak tanam dengan kultivar terhadap jumlah polong per tanaman. Pada Tabel 7 dapat dilihat bahwa pada semua kultivar jarak tanam tidak berpengaruh terhadap jumlah polong per tanaman. Namun pada jarak tanam $20 \mathrm{~cm}$ x $30 \mathrm{~cm}$, kultivar Murai menghasilkan polong yang paling sedikit sementara pada jarak tanam $25 \mathrm{~cm}$ x $30 \mathrm{~cm}$ kultivar Vima-1 menghasilkan polong paling banyak.

Beberapa penelitian menunjukkan jarak tanam tidak berpengaruh nyata terhadap jumlah polong per tanaman (Marsiwi et al., 2015; Rasul et al., 2012). Namun penelitian lain menunjukkan semakin lebar jarak tanam, jumlah polong yang dihasilkan per tanaman semakin banyak (Kabir dan Sarkar 2008). Jumlah polong per tanaman merupakan faktor utama dalam menentukan hasil pada tanaman kacang-kacangan (Rasul et al. 2012). Namun demikian, nampaknya jarak tanam merupakan sifat kuantitatif yang sangat 
dipengaruhi oleh lingkungan.

Tidak terjadi interakasi yang nyata antara jarak tanam dengan kultivar terhadap jumlah polong per petak, bobot 100 butir biji, dan indeks pane. Secara mandiri, jarak tanam berpengaruh nyata terhadap jumlah polong per petak, bobot 100 butir biji, dan indeks panen. Namun kultivar hanya berpengaruh nyata terhadap bobot 100 butir biji saja (Tabel 8).

Pada Tabel 8 dapat dilihat, bahwa pada jarak tanam yang rapat jumlah polong per petak yang dihasilkan paling sedikiti (544,78 buah) dibandingkan pada jarak tanaman yang lebih lebar. Namun demikian ketiga kultivar yang diuji menghasilkan jumlah polong per petak yang sama.

Bobot 100 butir biji atau bobot 1000 butir biji merupakan variabel yang digunakan untuk menentukan ukuran biji kacang hijau. Berdasarkan ukuran bijinya, kacang hijau dapat dikelompokkan menjadi tiga, yaitu berbiji besar (>61 g 1.000 biji $\left.^{-1}\right)$, berbiji sedang (5060 g 1.000 biji $\left.^{-1}\right)$, dan berbiji kecil (<50 g 1.000 biji $^{-}$ $\left.{ }^{1}\right)$ (Hakim 2008). Kultivar Walet, Murai dan Vima 1 dalam penelitian ini dapat dikelompokkan sebagai kultivar berbiji sedang.

Pada Tabel 8 dapat dilihat bahwa jarak tanam berpengaruh nyata terhadap bobot 100 butir biji. Ukuran biji yang paling besar diperoleh pada perlakuan jarak tanam $15 \mathrm{~cm}$ x $30 \mathrm{~cm}$ atau pada kultivar Walet. Ukuran biji yang lebih besar pada jarak tanam yang rapat diduga karena jumlah biji yang dihasilkan per tanaman lebih sedikit sementara pada jarak tanam yang lebar jumlah biji per tanaman diduga lebih banyak sehingga ukuran bijinya menjadi lebih kecil.

Indeks panen adalah ukuran potensi produktivitas fisiologis dari kultivar tanaman. Variabel ini menunjukkan kemampuan tanaman untuk mengubah bahan kering tanaman menjadi hasil ekonomi (Rasul et al. 2012).Indeks panen adalah rasio antara bobot kering biji (hasil ekonomi) dengan bobot kering tanaman (hasil biologi). Pada penelitian ini, kultivar Vima 1 memberikan indeks panen tertinggi dibanding kultivar

Tabel 8. Pengaruh Jarak Tanam dan Kultivar Terhadap Jumlah Polong per Petak, Bobot 100 butir Biji, dan Indeks Panen

\begin{tabular}{cccc}
\hline Perlakuan & $\begin{array}{c}\text { Jumlah Polong Per Petak } \\
(\text { Buah })\end{array}$ & $\begin{array}{c}\text { Bobot } 100 \text { butir Biji } \\
(\mathrm{g})\end{array}$ & Indeks Panen \\
\hline Jarak Tanam: & $544,78 \mathrm{a}$ & $8,09 \mathrm{~b}$ & $1,89 \mathrm{a}$ \\
$15 \mathrm{~cm} \times 30 \mathrm{~cm}$ & $431,42 \mathrm{~b}$ & $6,89 \mathrm{a}$ & $1,35 \mathrm{a}$ \\
$20 \mathrm{~cm} \times 30 \mathrm{~cm}$ & $615,89 \mathrm{~b}$ & $6,18 \mathrm{a}$ & $6,46 \mathrm{~b}$ \\
$25 \mathrm{~cm} \times 30 \mathrm{~cm}$ & & $7,69 \mathrm{~b}$ & $3,06 \mathrm{a}$ \\
Kultivar & $516,00 \mathrm{a}$ & $6,62 \mathrm{a}$ & $2,98 \mathrm{a}$ \\
Walet & $506,19 \mathrm{a}$ & $6,84 \mathrm{a}$ & $3,67 \mathrm{a}$ \\
Murai & $570,89 \mathrm{a}$ & & \\
Vima-1 & & &
\end{tabular}

Keterangan: Angka rata-rata yang diikuti huruf yang sama pada kolom yang sama menunjukan tidak berbeda nyata menurut LSD pada taraf $5 \%$. 
lainnya yang diuji, pada semua jarak tanaman yang diujikan. Hal ini menunjukkan bahwa kultivar Vima-1 lebih efisien dala memanfaatkan hasil fotosintat dibanding kultivar Walet dan Murai.

Interaksi yang nyata terjadi antara perlakuan jarak tanam dan kultivar terhadap bobot bijj kering per tanaman maupun per petak (hasil Uji F tidak ditampilkan). Pada bobot biji kering per tanaman, hasil tertinggi kultivar Walet diperoleh pada jarakt tanam 20 cm x $30 \mathrm{~cm}$, sementara kultivar Murai dan Vima-1 pada jarak tanam $15 \mathrm{~cm}$ x 30cm (Tabel 9).

Pada jarak tanam $20 \mathrm{~cm} \times 30 \mathrm{~cm}$ dan $25 \mathrm{~cm}$ x $30 \mathrm{~cm}$, Vima-1 memberikan hasil per tanaman yang paling tinggi dibandingkan dengan kultivar lain yang diuji. Hal ini disebabkan karena jumlah polong per tanaman yang dihasilkan juga paling banyak (Tabel 7). Pada jarak tanam yang lebih lebar, kompetisi antartanaman akan lebih kecil sehingga tanaman dapat memperoleh unsur hara, air, cahaya matahari secara optimal. Diduga kultivar Vima-1 lebih responsif dalam memanfaatkan kondisi tersebut dibanding dua kultivar lainnya.

Pada bobot biji kering per petak, jarak tanam yang lebih lebarmemberikan hasil yang lebih tinggi untuk kultivar Vima-1. Namun demikian, untuk kultivar Walet dan Murai baik jarak tanam $15 \mathrm{~cm}$ x $30 \mathrm{~cm}$ maupun $25 \mathrm{~cm}$ x $30 \mathrm{~cm}$ memberikan hasil yang sama (Tabel $10)$.

Tabel 9. Pengaruh Jarak Tanam dan Kultivar Terhadap Bobot Biji Kering PerTanaman

\begin{tabular}{cccc}
\hline Perlakuan & $15 \mathrm{~cm} \times 30 \mathrm{~cm}$ & $20 \mathrm{~cm} \times 30 \mathrm{~cm}$ & $25 \mathrm{~cm} \times 30 \mathrm{~cm}$ \\
\hline Walet & $58,29 \mathrm{a}$ & $95,11 \mathrm{a}$ & $32,26 \mathrm{a}$ \\
& $\mathrm{B}$ & $\mathrm{C}$ & $\mathrm{A}$ \\
Murai & $71,71 \mathrm{a}$ & $38,31 \mathrm{a}$ & $46,28 \mathrm{a}$ \\
& $\mathrm{B}$ & $\mathrm{A}$ & $\mathrm{A}$ \\
Vima-1 & $69,88 \mathrm{a}$ & $44,09 \mathrm{~b}$ & $62,44 \mathrm{~b}$ \\
& $\mathrm{~B}$ & $\mathrm{~A}$ & $\mathrm{~A}$ \\
\hline
\end{tabular}

Keterangan: Angka rata-rata yang diikuti huruf kapital yang sama pada baris yang sama dan huruf kecil yang sama pada kolom yang sama menunjukan tidak berbeda nyata menurut Uji LSD pada taraf $5 \%$.

Tabel 10 Pengaruh Jarak Tanam dan Kultivar Terhadap Bobot Biji Kering PerPetak (g)

\begin{tabular}{cccc}
\hline Perlakuan & $15 \mathrm{~cm} \times 30 \mathrm{~cm}$ & $20 \mathrm{~cm} \times 30 \mathrm{~cm}$ & $25 \mathrm{~cm} \times 30 \mathrm{~cm}$ \\
\hline Walet & $663,34 \mathrm{c}$ & $252,42 \mathrm{a}$ & $657,70 \mathrm{~b}$ \\
& $\mathrm{~B}$ & $\mathrm{~A}$ & $\mathrm{~B}$ \\
Murai & $337,46 \mathrm{~b}$ & $75,04 \mathrm{a}$ & $260,18 \mathrm{a}$ \\
& $\mathrm{B}$ & $\mathrm{A}$ & $\mathrm{B}$ \\
Vima-1 & $184,81 \mathrm{a}$ & $385,63 \mathrm{~b}$ & $259,93 \mathrm{a}$ \\
& $\mathrm{A}$ & $\mathrm{B}$ & $\mathrm{B}$ \\
\hline
\end{tabular}

Keterangan: Angka rata-rata yang diikuti huruf kapital yang sama pada baris yang sama dan huruf kecil yang sama pada kolom yang sama menunjukan tidak berbeda nyata menurut Uji LSD pada taraf $5 \%$. 
Pada semua jarak tanam, kultivar Walet memberikan hasil per petak yang paling tinggi. Pada jarak tanam yang paling rapat, Vima-1 memberikan hasil yang paling rendah semenara pada jarak tanam yang lebih lebar Murai memberikan hasil yang paling rendah. Hasil tertinggi kultivar Walet dan Murai diperoleh pada jarak tanam $15 \mathrm{~cm} x 30 \mathrm{~cm}(663,34 \mathrm{~g}$ petak $^{-1}$ dan 337,46 g petak ${ }^{-1}$ berturut-turut), sementara Vima-1 diperoleh pada jarak tanam $20 \mathrm{~cm}$ x $30 \mathrm{~cm}$ $\left(385,63 \mathrm{~g} \mathrm{petak}^{-1}\right)$.

\section{KESIMPULAN}

Terjadi interaksi yang nyata antara perlakuan jarak tanam dengan kultivar yang diuji terhadap indeks luas daun, jumlah polong per tanaman, bobot biji kering per tanaman dan bobot biji kering per petak. Jarak tanam berpengaruh nyata terhadap jumlah cabang per tanaman dan indeks luas daun pada umur 35 HST, jumlah polong per tanaman dan per petak, indeks panen, serta bobot biji kering per tanaman dan per petak. Hasil per petak tertinggi diperoleh dari kultivar Walet pada jarak tanam $15 \mathrm{~cm}$ x $30 \mathrm{~cm}$, yaitu 663,34g petak $^{-1}$.

\section{DAFTAR PUSTAKA}

Ahamed, Kamal Uddin, Kamrun Nahar, Mirza Hasanuzzaman, Golam Faruq, and Momena Khandaker. 2011. "Morphophysiological Attributes of Mungbean (Vigna Radiata L.) Varieties under Different Plant Spacing." World Journal of Agricultural Sciences 7 (2): 234-45.
Arsyadmunir, Ahmad. 2016. "Periode Kritis Kekeringan Pada Pertumbuhan dan Produksi Kacang Hijau (Vigna Radiata L.)." AGROVIGOR 9 (2): 132-40. http:// journal.trunojoyo.ac.id/agrovigor/article/view/ 2319.

Chaniago, Noverina, Deddy Wahyudin Purba, and Algi Utama. 2017. "Respon Pemberian Pupuk Organik Cair (POC) Bonggol Pisang Dan Sistem Jarak Tanam Terhadap Pertumbuhan Dan Produksi Kacang Hijau (Vigna Radiata L. Willczek)." Jurnal Penelitian Pertanian BERNAS 13 (1): 1-8.

Hakim, L. 2008. “Konservasi Dan Pemanfaatan Sumber Daya Genetik Kacang Hijau." Jurnal Litbang Pertanian 27 (1): 16-23. ht t p://dx.doi.org/10.21082/ jp3.v27n1.2008.p16-23.

Hopkins, Willian G., and Norman P.A. Hunner. 2009. Introduction to Plant Physiology. $4^{\text {th }}$ ed. London: John Willey \& Sons.

Kabir, M. H., and M.A. R. Sarkar. 2008. "Seed Yield of Mungbean as Affected by Variety and Plant Spacing in Kharif-I Season." J. Bangladesh Agril. Univ. 6(2): 239-44. https:/ /doi.org/10.22004/ag.econ.208297.

Kuntyastuti, Henny, and Sri Ayu Dwi Lestari. 2017. "Pengaruh Interaksi Antara Dosis Pupuk Dan Populasi Tanaman Terhadap Pertumbuhan Dan Hasil Kacang Hijau Pada Lahan Kering Beriklim Kering." Jurnal Penelitian Pertanian Tanaman Pangan 35 (3): 239-50.

Marliah, Ainun, Taufan Hidayat, and Nasliyah Husna. 2012. "Pengaruh Varietas Dan Jarak Tanam 
Terhadap Pertumbuhan Kedelai [Glycine Max (L.) Merrill]." Jurnal Agrista 16 (1): 22-28. http:/jurnal.unsyiah.ac.id/index.php/ agrista/article/view/679.

Marsiwi, Tri, Setyastuti Purwanti, and Djoko Prajitno. 2015. "Pengaruh Jarak Tanam Dan Takaran Pupuk NPK Terhadap Pertumbuhan Dan Hasil Benih Kacang Hijau (Vigna radiata L. Wilczek)." Vegetalika 4 (2): 124-32. https:// scholar.google.co.id//scholar?hl=id\& as_sdt $=0 \% 2 \mathrm{C} 5 \& \mathrm{q}=\mathrm{PENGARUH}+\mathrm{JARAK}+$ TANAM+DAN+TAKARAN+PUPUK+NPK+ TERHADAP+ PERTUMBUHAN+DAN + HASIL +BENIH+KACANG+ HIJAU \&btnG $=$.

Putra, I Putu Panca Diantara, Gede Wijana, and Ketut Kartha Dinata. 2016. "Kajian Jumlah Biji per Lubang Tanam Dan Paket Pupuk Terhadap Pertumbuhan Dan Hasil Kacang Hijau (Vigna radiata L.) Varietas Vima-1." Agrotrop 6 (1): 73-82.

Radjit, Budhi Santoso, and Nila Prasetiaswati. 2012. "Prospek Kacang Hijau Pada Musim Kemarau Di Jawa Tengah." Buletin Palawija 24: 57-68.

Rasul, F., M. A. Cheema, A. Sattar, M. F. Saleem, and M. A. Wahid. 2012. "Evaluating the Performance of Three Mungbean Varieties Grown under Varying Inter-Row Spacing." Journal of Animal and Plant Sciences 22 (4): 1030-35.

Seran, Yohanes Leki, Medo Kote, and Frederikus L. Benu. 2011. "Pengembangan Kacang Hijau Varietas Unggul Vima-1 Di Kabupaten Belu,
NTT." In Seminar Hasil Penelitian Tanaman Aneka Kacang Dan Umbi 2011, 546-53.

Sunghening, Wiwara, Tohari, dan Dja'far Shiddieq. 2013. "Pengaruh Mulsa Organik Terhadap Pertumbuhan Dan Hasil Tiga Varietas Kacang Hijau (Vigna Radiata L. Wilczek) Di Lahan Pasir Pantai Bugel, Kulon Progo." Vegetalika 1 (2): 1-13. https:// journal.ugm.ac.id/jbp/article/view/1519.

Trustinah, B. S. Radjit, N. Prasetiaswati,dan D. Harnowo. 2014. "Adopsi Varietas Unggul Kacang Hijau Di Sentra Produksi." Iptek Tanaman Pangan 9 (1): 24-38. 